\title{
Survey of Haemorrhagic Erosive Gastritis
}

\author{
C. E. R. THOMPSON,* M.A., M.B., F.R.C.S.ED. ; P. M. ASHURST, † M.B., B.SC. ; T. J. BUTLER; M.D., F.R.C.S.
}

Brit. med. F., 1968, 3, 283-285

\begin{abstract}
Cummary : Fluorescent-antibody studies in 22 patients $\checkmark$ out of a total of $\mathbf{4 0}$ cases of acute erosive gastritis showed no antibodies to gastric parietal cells. Hence erosive gastritis seems unlikely to be an autoimmune phenomenon.
\end{abstract}

In this series $57.5 \%$ of cases belonged to blood group A. This suggests that there is a correlation between the instability of the gastric mucosa and blood group $A$.

The operative mortality in erosive gastritis is high. Operation should be delayed as long as possible in the hope that the bleeding will stop spontaneously. Erosive gastritis may be idiopathic or precipitated by drugs, particularly aspirin. The highest risk was found to occur in those cases where bleeding was drug-induced.

\section{Introduction}

Accurate diagnosis of the cause and site of upper gastrointestinal bleeding is of paramount importance in planning the correct treatment.

The mortality from such haemorrhage increases with age, particularly if operation becomes necessary to control it. The policy in our unit is to delay surgery longer than is usual in many hospitals in the hope that conservative measures such as blood transfusion, and, in massive haemorrhage, gastric cooling, as recommended by Capper and Buckler (1964), may prove successful. Non-operative treatment is usually successful in cases of erosive gastritis.

While these measures are being tried time is available for ascertaining the site and cause of the bleeding. A barium-meal examination is carried out as soon as possible after admission. A diagnosis of erosive gastritis may be suspected in cases where barium studies are negative and there is no history of dyspepsia, and gastroscopy may then be performed for confirmation. This diagnosis is therefore based on clinical rather than pathological grounds (cf. Parry and Wood, 1967).

The lack of knowledge about the aetiology and natural history of erosive gastritis prompted us to investigate its relation to blood group, to the acid status of gastric mucosa, to operative mortality, and to the ingestion of drugs. The occurrence of parietal cell antibodies in association with atrophic gastritis (Mackay, 1964) led us to search for such antibodies in cases of erosive gastritis. The finding of antibodies would throw further light on the aetiology of this condition. At the same time we felt it might be possible to develop a diagnostic screening test which could be used in units where facilities were available.

\section{Material and Methods}

In the three-year period 1964-6 a total of 270 cases of gastroduodenal haemorrhage were admitted to this unit as emergencies. The details are shown in Table I. Table II shows the age and sex incidence of the 40 patients in whom a diagnosis

\footnotetext{
- Locum Consultant Surgeon, Frenchay Hospital, Bristol.

t Research Registrar, Frenchay Hospital, Bristol.
}

of erosive gastritis was made. This diagnosis was made only in the absence of any dyspeptic history, together with negative barium studies and either positive gastroscopic or laparotomy findings, where these were performed.

TABLE I.-Emergency Admissions With Upper Gastrointestinal Bleeding

\begin{tabular}{|c|c|c|c|c|c|c|}
\hline & & 1964 & 1965 & 1966 & Total & $\%$ \\
\hline $\begin{array}{l}\text { Gastric ulcer } \\
\text { Duodenal ulcer } \\
\text { Erosive gastritis } \\
\text { Others } \quad . .\end{array}$ & 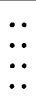 & $\begin{array}{r}29 \\
62 \\
11 \\
1\end{array}$ & $\begin{array}{r}28 \\
48 \\
10 \\
2\end{array}$ & $\begin{array}{r}20 \\
40 \\
19 \\
0\end{array}$ & $\begin{array}{r}77 \\
150 \\
40 \\
3\end{array}$ & $\begin{array}{l}28.5 \\
55.8 \\
14.6 \\
1.1\end{array}$ \\
\hline Total .. & .. & 103 & 88 & 79 & 270 & \\
\hline
\end{tabular}

\begin{tabular}{|c|c|c|c|c|c|c|c|c|c|c|}
\hline & & \multicolumn{8}{|c|}{ Age in Decades } & \multirow{2}{*}{ Total } \\
\hline & & 2 & 3 & 4 & 5 & 6 & 7 & 8 & 9 & \\
\hline $\begin{array}{l}\text { Males } \\
\text { Females }\end{array}$ & $\because$. & $\begin{array}{l}2 \\
0\end{array}$ & $\begin{array}{l}2 \\
0\end{array}$ & $\begin{array}{l}2 \\
1\end{array}$ & $\begin{array}{l}4 \\
1\end{array}$ & $\begin{array}{l}3 \\
4\end{array}$ & $\begin{array}{l}2 \\
5\end{array}$ & $\frac{1}{7}$ & $\begin{array}{l}2 \\
4\end{array}$ & $\begin{array}{l}18 \\
22\end{array}$ \\
\hline
\end{tabular}

\section{Testing for Parietal Cell Antibodies}

This survey was begun in 1965. The search for antibodies was therefore partly retrospective. Tests were performed on blood taken after the emergency admission in more than half the cases studied. Eighteen cases were lost to follow-up either through death or because they could not be traced. Of the other 22 cases 12 were interviewed either in the patient's home or in the outpatient department. There was an interval of four months to two and a half years from the time of hospital admission to the time of interview. Blood samples were taken from each of these patients. The remaining 10 patients were seen in hospital immediately after their emergency admission and a blood sample was taken before any blood transfusion was given.

From each of the 22 patients studied $10 \mathrm{ml}$. of blood was taken and the serum obtained after centrifuging was stored in aliquots at $-4^{\circ} \mathrm{C}$. The sera were coded and examined "blind" among sera from patients with haemorrhage from other causes and from patients with duodenal ulcer, gastric ulcer, and gastric carcinoma. Known positive serum was obtained from a series of patients with pernicious anaemia who had been tested previously.

Human stomach fundus and kidney were obtained fresh at surgical operation and were snap-frozen within 10 minutes. Calf thyroid was obtained from a local abattoir and similarly frozen. The tissues were stored at $-70^{\circ} \mathrm{C}$. to preserve antigenicity.

Fluorescent Antiglobulin Serum.-Burroughs Wellcome \& Co. kindly supplied their routine commercial anti-human gammaglobulin serum conjugated with fluorescein isothiocyanate. Each millilitre was absorbed with $100 \mathrm{mg}$. of liver powder before use. The fluorescent serum was found to give adequate results at a dilution of $1: 4$ with phosphate-buffered

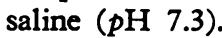

Immunofluorescent Staining Procedure.-Portions of each of the three tissues were mounted close together on a chuck, and cryostat sections of $4 \mu$ thickness were dried at room 
temperature. The sections were covered with serum, which had been allowed to reach room temperature for 30 minutes in a moist box, and then washed for 10 minutes in phosphatebuffered saline. Fluorescent antiglobulin was then applied for 40 minutes, and after further washing with buffer for 10 minutes the sections were mounted in Uvinert aqueous mountant (George Gurr Ltd.). At no time were the sections allowed to dry out.

\section{Blood Group}

The ABO blood group for 30 patients who needed blood transfusion was determined on admission. From the remaining 10 patients who did not require transfusion blood was taken, so that the group could be determined at the same time that blood was taken for antibody staining.

\section{Gastric Acidity}

In all patients who were subjected to operation the opened stomach was tested for free acid with Universal indicator paper.

In three cases a nasogastric tube was passed after the bleeding had stopped, and the aspirate tested for acid.

\section{Results}

Parietal Cell Antibodies.-The slides were examined under dark-ground illumination with a Gillett and Sibert Conference microscope. No antibodies to gastric parietal cells, gastric mucous cells, or to calf thyroid were found. Antinuclear antibodies were present in only one specimen, but this was positive only at a dilution of less than $1: 10$.

Blood Group.-The distribution of blood groups is shown in Table III : $57.5 \%$ were group A, while $37.5 \%$ were group 0 .

Gastric Acidity.-In all patients who were studied, either at operation or by gastric aspiration, achlorhydria was found.

\begin{tabular}{cc|c|c|c|c}
\multicolumn{7}{c}{ TABLE III.-Blood Group Incidence } \\
\hline & & A & O & B & Total \\
\hline Male $\cdots$ & $\cdots$ & 12 & 5 & 1 & 18 \\
\hline Female & $\cdots$ & 11 & 10 & 1 & 22 \\
\hline Total & $\cdots$ & $23(57 \cdot 5 \%)$ & $15(37 \cdot 5 \%)$ & $2(5 \%)$ & 40 \\
\hline
\end{tabular}

\section{Discussion}

The primary aim of this study was to look for the presence of gastric antibodies in cases of erosive gastritis presenting with haemorrhage. It was hoped that it might be possible to use fluorescent staining to demonstrate antibody fixation as a screening test in the diagnosis of this condition. In 15 of the 40 cases under investigation gastroscopy was carried out and erosive gastritis was demonstrated in 14 of them. In the remaining case gastroscopy was negative and the diagnosis was made at laparotomy. In four other cases the diagnosis was made at laparotomy without previous gastroscopy. In 21 cases the diagnosis rests solely on negative barium studies together with the clinical history. A further diagnostic aid would therefore be most useful.

The antibody tests, however, are not conclusive. In only 10 cases was serum obtained at the time of the acute condition and before blood transfusion was given, though no antibody was found in any of these. While 30 cases remain in which blood was either not available for study or was taken after the emergency admission, it would appear to be significant that no antibodies were found in the 10 cases in which immediate blood samples were taken.
Coghill et al. (1965), investigating 47 cases of gastritis, found that $62 \%$ of females and $12.5 \%$ of males had parietal cell antibodies when the pathology was atrophic gastritis. Their series included nine cases of superficial gastritis, but no specific mention is made whether antibodies were present in them. If antibodies were present it would be reasonable to assume that they would be against the parietal cell, as it is the acid secretion of the stomach which is temporarily depressed. Langmann et al. (1964) reported that acute erosions were found in atrophic mucosa. Our findings do not support this, as the latter condition is often associated with autoantibodies.

In spite of these negative findings certain other factors concerning erosive gastritis came to light. A preliminary report of some of these factors was given by Butler (1967), and his statements are expanded below.

\section{Blood Group}

There was a marked preponderance of group A $(57.5 \%)$, while $37.5 \%$ were group $O$. With $42 \%$ incidence of blood group $\mathrm{A}$ in the general population, the figure for group $\mathrm{A}$ in this series is just statistically significant at the 1 in 20 level of probability. There appear to be no other reports showing a statistically significant relation between erosive gastritis and blood group A. In the literature up to the present an increased risk of bleeding from the upper gastrointestinal tract is generally associated with blood group O (Horwich et al., 1966) and with non-secretor status. This latter aspect was not investigated in our study.

\section{Mortality}

The highest mortality was in those who came to laparotomy. Of five who underwent surgery three died, an operative mortality of $60 \%$. All three continued to bleed after operation. The overall mortality was $10 \%$ (four cases). Details of patients who died are given in Table IV. All deaths occurred in those who had taken aspirin, and three out of four were blood group A. This suggests that these two factors in combination make the bleeding more severe and of longer duration. These figures contrast with an operative mortality of $14 \%$ in cases of bleeding duodenal and gastric ulcer over the same period of time and an overall mortality of $6 \%$ in these cases. This compares with an overall mortality of $7.7 \%$ in bleeding gastric and duodenal ulcer reported by Avery Jones (1961).

\begin{tabular}{|c|c|c|c|c|c|}
\hline Age & Sex & Cause of Death & $\begin{array}{l}\text { Blood } \\
\text { Group }\end{array}$ & Cause & Treatment \\
\hline $\begin{array}{l}34 \\
34 \\
84 \\
70\end{array}$ & $\begin{array}{l}\text { Male } \\
\text { Male } \\
\text { Male } \\
\text { Female }\end{array}$ & $\begin{array}{l}\text { Renal failure } \\
\text { Renal failure } \\
\text { Bronchopneumonia } \\
\text { Coronary thrombosis }\end{array}$ & $\begin{array}{l}\mathbf{A} \\
\mathbf{O} \\
\mathbf{A} \\
\mathbf{A}\end{array}$ & $\begin{array}{l}\text { Codis } \\
\text { Codis } \\
\text { Codis } \\
\text { Aspirin }\end{array}$ & $\begin{array}{l}\text { Operation } \\
\text { Operation } \\
\text { Operation } \\
\text { Conservative }\end{array}$ \\
\hline
\end{tabular}

Until the aetiology and pathology of this condition are understood, and a complete and rational treatment has been worked out, it seems that operative treatment should be avoided because of its high mortality.

Carruthers et al. (1967) reported 13 cases of erosive gastritis treated by operation. Of four patients treated by gastrectomy one died after a further bleed. Out of nine receiving more conservative surgical treatment three bled again; two of these died. Those authors recommend vagotomy to anticipate the return of acid secretion. It seems that if operation becomes necessary a combination of these two approaches should be used-namely, hemigastrectomy to reduce the bleeding surface and vagotomy to protect the mucosa and to open up the submucous arteriovenous shunts. We found that undersewing the erosions was not practicable, unless they were very large, owing to the extreme friability of the mucosa. In three of our cases 
these procedures were combined with Roux-en-Y anastomosis to protect the stomach from the effects of biliary reflux (Capper et al., 1967). In the two remaining cases vagotomy and pyloroplasty was done because of the extremely poor condition of the patient, and the larger erosions were undersewn. Both these patients continued to bleed. One required further more radical surgery and the other died.

\section{Relation to Drugs}

The cases under investigation could be divided into two groups according to whether or not the bleeding was preceded by the ingestion of drugs. Table $\mathrm{V}$ shows the incidence of drug-induced and idiopathic bleeding.

TABLE V.-Incidence of Drug-induced and Idiopathic Bleeding

\begin{tabular}{|c|c|c|c|c|c|c|}
\hline \multicolumn{4}{|c|}{ Bleeding } & \multirow{2}{*}{$\begin{array}{c}\text { Male } \\
8 \\
13\end{array}$} & \multirow{2}{*}{$\begin{array}{c}\text { Female } \\
7 \\
12\end{array}$} & \multirow{2}{*}{$\begin{array}{c}\text { Total } \\
\begin{array}{c}15 \\
25\end{array}\end{array}$} \\
\hline $\begin{array}{l}\text { Idiopathic } \\
\text { Drug-induced }\end{array}$ & 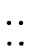 & 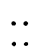 & 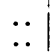 & & & \\
\hline Total . & $\ldots$ & $\ldots$ & .. & 21 & 19 & 40 \\
\hline
\end{tabular}

Twenty-five cases were thought to be drug-induced. The drugs implicated were aspirin (12 cases), alcohol (6 cases), butazolidin ( 5 cases), and steroids ( 2 cases). All four patients who died had drug-induced bleeding. This poses a problem in management. Bleeding which was drug-induced appeared to persist longer than idiopathic bleeding, making operation seem advisable; yet, retrospectively, this carries a higher mortality. On balance it seems that operation should be withheld if possible.

\section{Gastric Secretion}

In all patients who were subjected to operation the opened stomach was tested for acid with Universal indicator paper, and achlorhydria was found. Similarly, three cases were tested for acid by passing a gastric tube after the bleeding had stopped. Achlorhydria was found in each case.
Gastroscopic and naked-eye appearances at operation showed globular mucus, a known accompaniment of hypochlorhydria and achlorhydria.

Davenport (1964) showed that the mucosal barrier to hydrogen ions can be disrupted by various insults, of which aspirin is one (Lynch et al., 1964 ; Croft and Wood, 1967 ; Parry and Wood, 1967). Our findings would support this theory, and, as erosive gastritis is probably not an autoimmune phenomenon, this state is likely to be reversible when the insult is removed. The achlorhydria that we found is probably due not to increased acid production but to reabsorption of the hydrogen ions from the gastric lumen. However, Køster et al. (1955) reported their finding of an increased incidence of blood group $\mathbf{A}$ in association with hypochlorhydria.

The recovery of acid production after an episode of haemorrhagic erosive gastritis remains to be studied in a further series, but the likelihood of its recovery is the reason for the nature of the surgical treatment which we recommend.

Our thanks are due to Dr. R. J. Sandry and members of his staff for facilities made available in the laboratory ; to Miss E. H. L. Duncan, of the University of Bristol, for statistical help ; and to Dr. J. M. Naish for assistance with the preparation of this paper.

\section{REFERENCES}

Butler, T. J. (1967). Brit. med. F., 1, 360.

Capper, W. M., and Buckler, K. G. (1964). Brit. Y. Surg., 51, 752.

Capper, W. M., Butler, T. J., and Kilby, J. O. (1967). Gut, 8, 612. Carruthers, R. K., Giles, G. R., Clark, C. G., and Goligher, J. C. (1967). Brit. med.. ., 1,80 .

Coghill, N. F., Doniach, D., Roitt, I. M., Mollin, D. L., and Williams, A. W. (1965). Gut, 6, 48 .

Croft, D. N., and Wood, P. H. N. (1967). Brit. med. F., 1, 137.

Davenport, H. W. (1964). Gastroenterology, 46, 245

Horwich, L., Evans, D. A. P., McConnell, R. B., and Donohoe, W. T. A. (1966). Gut, 7, 680 .

Jones, F. A. (1961). In R. Maingot's Abdominal Operations, 4th ed., Jones, F. A. (1961). In

Køster, K. H., Sindrup, E., and Seele, V. (1955). Lancet, 2, 52.

Langmann, M. J. S., Hansky, J. H., Drury, R. A. B., and Jones, F. A. (1964). Gut, 5, 550 .

Lynch, A., Shaw, H., and Milton, G. W. (1964). Gut, 5, 230

Mackay, I. R. (1964). Gut, 5, 23.

Parry, D. J., and Wood, P. H. N. (1967). Gut, 8, 301.

\title{
Resistance to Suppression by Dexamethasone of Plasma 11-O.H.C.S. Levels in Severe Depressive Illness
}

\author{
B. J. CARROLL,* M.B., B.S., B.SC. ; F. I. R. MARTIN, $\dagger$ M.D., F.R.A.C.P. \\ BRIAN DAVIES, $\ddagger$ M.D., M.R.C.P., D.P.M., D.C.H., M.A.N.Z.C.P.
}

Brit. med. F., 1968, 3, 285-287

\begin{abstract}
Summary : Use of the midnight dexamethasone suppression test showed that the plasma 11-hydroxycorticosteroid (11-O.H.C.S.) level did not undergo its normal reduction in 14 out of 27 patients with severe depression. Resistance to dexamethasone suppression correlated with the clinical rating of the severity of depression, while recovery from depression was associated with return of normal responsiveness to dexamethasone. The explanation of these findings is unknown.
\end{abstract}

\footnotetext{
* Medical Research Fellow, Department of Psychiatry, University of Melbourne.

† Endocrinologist, the Royal Melbourne Hospital.

$\ddagger$ Cato Professor of Psychiatry, University of Melbourne, Clinical Sciences Building, Royal Melbourne Hospital, Victoria, Australia.
}

Evidence suggestive of increased adrenocortical activity in depression has been widely reported and recently reviewed by Fawcett and Bunney (1967) and Coppen (1967). The midnight dexamethasone suppression test has been extensively used in the assessment of patients with clinical evidence of adrenocortical overactivity to define normal feedback control (Nugent et al., 1965 ; McHardy-Young et al., 1967). We report our experience with this test in the assessment of adrenocortical function in patients with severe depressive illness.

\section{Subjects and Methods}

Twenty-seven patients with severe depressive illness admitted consecutively to the professorial psychiatric unit were studied. 